https://helda.helsinki.fi

Women out of Place : The Women Who Challenged Jesus

\title{
Asikainen, Susanna
}

2018

Asikainen , S 2018 , ' Women out of Place : The Women Who Challenged Jesus ', Neotestamentica, vol. 52 , no. 1 , pp. 179-193 . https://doi.org/10.1353/neo.2018.0000

http://hdl.handle.net/10138/318835

https://doi.org/10.1353/neo.2018.0000

publishedVersion

Downloaded from Helda, University of Helsinki institutional repository.

This is an electronic reprint of the original article.

This reprint may differ from the original in pagination and typographic detail.

Please cite the original version. 


\title{
Women out of Place: The Women Who Challenged Jesus
}

\author{
Susanna Asikainen \\ University of Helsinki
}

\begin{abstract}
Although the Gospels include several stories in which Jesus interacts with women, the women themselves often have very limited roles in these narratives. However, there are also women who do not submit to the traditional ideals of emphasised femininity, which included silence and submissiveness. In this article, I study three women who challenge Jesus: the Syrophoenician woman in the Gospel of Mark, and Jesus's mother and the Samaritan woman in the Gospel of John. How did these women shape and change Jesus's understanding of his mission? What implications did these narratives have for the women's femininity and Jesus's masculinity? In these narratives, Jesus attempts to put these unruly women back into their proper place. Previous studies have downplayed or excused the rudeness of Jesus's actions and words. Undaunted by Jesus's behaviour, the three women refuse to be silenced. Not only are these three women "out of place," their behaviour also calls Jesus's masculinity into question.
\end{abstract}

\section{Key Terms}

Gospels; women; Jesus; femininity; masculinity

\section{Introduction}

The words of a modest woman must never be public property. She should be shy with her speech as with her body, and guard it against strangers. (Plutarch, Advice to the Bride and Groom 31)

The idea that women should be silent in public had proverbial status in the ancient Greco-Roman world. ${ }^{1}$ The silence and submissiveness of a woman

\footnotetext{
1 I want to thank the anonymous reviewers, whose comments helped improve and clarify this article.
}

Neotestamentica 52.1 (2018) 179-193

(C) New Testament Society of Southern Africa 
exhibited her ideal feminine behaviour. Using Raewyn Connell's terminology, these traditional ideals of femininity can be called "emphasized femininity." Emphasised femininity can be characterised as compliance with the subordination of women. It is also "oriented to accommodating the interests and desires of men" (Connell 1987, 183-187). In the ancient Greco-Roman world, emphasised femininity included domestic virtues, chastity, modesty and marital fidelity. ${ }^{2}$ Plutarch thus provides an example of traditional thinking when it came to defining what ideal women were supposed to be like. Similarly, very often in the Gospel stories, women are simply featured as props. Although the Gospels include several accounts of Jesus meeting and interacting with women, these women often have very limited roles. Women may exemplify ideal behaviour, but the men are the ones who discuss and evaluate this behaviour. The women themselves remain silent.

The Gospels in general could be called phallogocentric. According to Marianne Bjelland Kartzow $(2009,25)$, "[w]omen mentioned in phallogocentric texts are there only to illustrate a point, not as persons or individuals. Women are there for men, in order to point at something else or as an illustration, or they are silenced or eliminated completely." This is what happens in the Gospels. Illustrative examples are the stories of Peter's mother-in-law, the bent woman and the woman who anoints Jesus. Peter's mother-in-law does not ask for healing; others request it for her (Mark 1:2931; Matt 8:14-15; Luke 4:38-39). In the story of the bent woman, the healing of the female figure is not as important as the dispute with the male leader of the synagogue. The issue is not that Jesus heals a woman, but that he heals on the Sabbath. The woman does not ask for healing; she serves more as a prop for Jesus's teaching (Luke 13:10-17). In both of these accounts, the women play a traditionally silent role while others act on their behalf. The anointing woman, whether she is described as a sinner or not, also remains silent while Jesus and other men discuss her behaviour (Mark 14:3-9; Matt 26:6-13; Luke 7:36-50). These women fulfilled the ideals of emphasised femininity. However, there are also women who do not remain

\footnotetext{
2 E.g., Musonius Rufus (That Women Too Should Study Philosophy; Should Daughters Receive the Same Education as Sons?) maintained that a woman should be a good housekeeper, but the most important qualities for a woman were chastity and self-control. Plutarch teaches in his Advice to the Bride and Groom that the ideal wife was selfcontrolled and modest, silent and submissive. Susan Treggiari (1991, esp. 229-261) notes that Latin epitaphs mention such virtues as chastity, being married only once (univira), faith, respect and co-operation, and kindness.
} 
silent in the Gospels. In this article, I study three women who speak out and challenge Jesus: the Syrophoenician woman in the Gospel of Mark, and Jesus's mother and the Samaritan woman in the Gospel of John.

I call these women "out of place." In the ancient Greco-Roman writings, it was often maintained that women should remain in private places and men should occupy public spaces (see, e.g., Philo, On the Special Laws 3.169; Xenophon, Oeconomicus 7.22). However, this was more of an ideal than a reality. Only in very wealthy families could women be kept secluded at home, and even those women did move outside their homes to attend, for example, religious festivals and possibly even theatrical performances. Moreover, men also stayed at home (Økland 2004, 58-66). The division between public and private was not as clear-cut as the ancient writers make it seem. Still, in the ancient Greco-Roman ideology, the concepts of honour and shame were connected with place. It was shameful for a person to be out of place: a woman who had too public a role was unsuitably masculine, and a man who remained indoors too much was effeminate.

The Syrophoenician woman, Jesus's mother and the Samaritan woman are not necessarily out of place physically. These women speak to Jesus in a house, at a wedding feast, and by a well. The women do not transgress social customs when coming to these places. Nevertheless, the behaviour of these women renders them "out of place." They do not submit to the authority of a male figure. Thus, their behaviour is "shameless." Halvor Moxnes $(2003,52)$ notes that shame can be incurred "by going beyond one's place, not respecting one's position within the community." Systems of gender can be used as ways of "putting people in their places" (Moxnes 2003, 4). People who go beyond their proper place in the community may have their masculinity and/or femininity called into question. Other people may attempt to shame them and put them back into their place.

In this article, I consider how women who were out of place shaped and changed Jesus's understanding of his mission. How do these women act in comparison to the ideals of emphasised femininity? How does their behaviour affect Jesus's masculinity? In masculinity studies, it has become commonplace to talk about masculinities in the plural. This is because every culture has several masculinity ideals. Raewyn Connell (1987, 183-186; 2005, 76-81) differentiates between hegemonic and non-hegemonic masculinities. Hegemonic masculinity is the masculinity ideal of the dominant group. In addition, each culture also has several non-hegemonic 
masculinities. Important in this context is also the concept of hypermasculinity. Hypermasculinity is not necessarily synonymous with hegemonic masculinity, but refers rather to the exaggeration of stereotypical behaviour of men, which may include an emphasis on sexual and physical aggression.

In the ancient Greco-Roman world, in order to be hegemonically masculine, a man needed be able to control women and demonstrate authority (see, e.g., Asikainen 2018; Williams 1999, 133, 138). Is Jesus depicted in the three chosen narratives as a hegemonically masculine man, or, in other words, does he control these three women?

\section{The Syrophoenician Woman (Mark 7:24-30)}

In the Gospel of Mark, a Syrophoenician woman challenges Jesus and persuades him into giving her what she wants, thereby securing healing for her daughter. Being a persuasive speaker was an important characteristic of masculinity in the ancient Greco-Roman world. The woman exhibits this masculine characteristic, but Jesus's masculinity, on the other hand, is called into question when a woman manages to persuade him.

Jesus goes to the gentile region of Tyre and enters a house, wishing to remain incognito. The Syrophoenician woman invades Jesus's privacy, bows down in front of him, and asks him to heal her daughter. Instead of healing the daughter as he has done for several other supplicants, Jesus responds with a parable: "Let the children be fed first, for it is not fair to take the children's bread and throw it to the dogs" (Mark 7:27). ${ }^{3}$ Commentators have often sought to soften Jesus's harsh words. Based on the use of the diminutive form kvvópıov ("little dog"), they claim that Jesus talks about "puppies" or "pet dogs." They argue that Jesus's words only appear to be an insult, and should not be taken at face value. ${ }^{4}$ Several commentators also maintain that Jesus's words refer to a domestic setting: the dogs are under the table (Gundry 1994, 315; Luz 2001, 340; Keener 1999, 416; Nolland 2005, 634).

\footnotetext{
3 Unless otherwise noted, translations follow NRSV.

4 These commentators suggest various interpretations: that Jesus was talking to himself (Taylor 1952, 350); that his expressions or tone of voice hinted to the woman that his refusal was not final (Filson 1971, 180; France 2007, 591); that he was testing the woman's faith (Keener 1999, 417; Lane 1975, 262).
} 
I argue that the offensive nature of the passage should not be overlooked. Calling someone a dog was a common insult in Jewish writings and Greco-Roman literature from Homer onwards. ${ }^{5}$ In ancient Israel, dogs were not household pets, but street animals that scavenged for food (1 Kgs $14: 11 ; 21: 23$; Luke 16:21). ${ }^{6}$ It is clear that Jesus's saying is meant as an insult. As T. A. Burkill $(1967,173)$ notes, "to call a woman 'a little bitch' is no less abusive than to call her 'a bitch' without qualification." The woman changes the meaning of Jesus's parable in her answer. While Jesus is talking about dogs that are outside the house, the woman introduces the notion of the table, thereby transforming the context.

The Syrophoenician woman answers with a parable of her own. It is important to note that she does not concur with Jesus, but says: "Sir, even the dogs under the table eat the children's crumbs" (Mark 7:28). Her statement represents a disagreement with Jesus. ${ }^{7}$ This becomes more evident when compared with how the Gospel of Matthew changes the woman's answer. Matthew adds "yes" to the beginning of her answer, thereby turning it into an agreement (Matt 15:27). In Matthew, the woman explicitly agrees with Jesus. In Mark, the woman's answer challenges Jesus's authority and thereby also his masculinity.

Mark portrays the woman as accepting the traditional subordinate status of her gender. Her posture is submissive. She talks about dogs that are under the table, where they present no threat to the children's higher status. However, her disagreement with Jesus is in itself challenging and extends beyond the traditional feminine role. Her willingness to transgress social boundaries means that her behaviour is not in accordance with the ancient Greco-Roman ideals of emphasised femininity.

As a result of the woman's retort, Jesus changes his mind and heals her daughter. The Syrophoenician woman is an exceptional figure, because she is the only person in the Synoptic Gospels to best Jesus in a dispute.

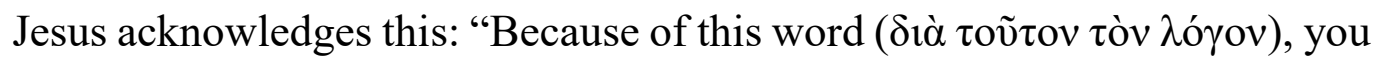

5 See, e.g., Homer, Iliad 8.527; 9.373; 11.362; 20.449; Odyssey 17.248; 18.338; 19.91; 22.35. For "dog" as an insult in the OT, see, e.g., 1 Sam 17:43; 2 Sam 16:9; Isa 56:10-11; Ps 22:16, 20. The dog was also a despised animal in the NT (see, e.g., Phil 3:2; Rev 22:15).

6 Mentions of scavenger dogs can be found in classical Greek writings as well; see, e.g., Homer, Iliad 17.127; 22.42-43, 66-70, 335-36, 339; 23.21; 24.211; Odyssey 3.258-260; 21.363-364; 22.476. See also Von Lips $(1988,176)$.

7 Some manuscripts make the woman's response markedly affirmative by adding "yes" at the beginning of v. 28. However, this is probably influenced by the Matthean parallel (Metzger 1994, 82; Alonso 2011, 65). 


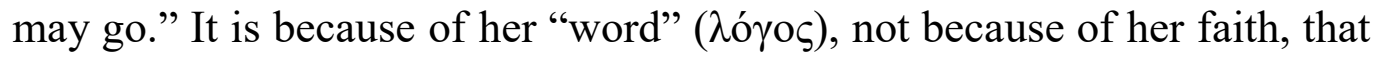
Jesus cures her daughter. ${ }^{8}$

It is important to note that Jesus's change of heart was not a mere exception for this woman. What is even more remarkable is that after the encounter with the Syrophoenician woman, Jesus changes his strategy. In the following episodes, Jesus travels through gentile lands, where he heals and feeds people (Mark 7:31-8:9). ${ }^{9}$ Thus, this meeting can be called the turning point in Mark's Gospel, where the breakthrough to a mission among gentiles occurs (see also Rhoads 1994, 348).

The encounter with the Syrophoenician woman is the only instance in the Gospels where Jesus loses a dispute - and to a gentile woman, no less. How does this affect Jesus's masculinity? When the woman disagrees with Jesus, she threatens his authority and thus his masculinity. Her response to Jesus challenges him to reconsider his mission. Moreover, Jesus acknowledges that the woman's words persuaded him to change his mind. From the point of view of traditional gender ideals, the encounter with the Syrophoenician woman calls Jesus's masculinity into question. Jesus does not succeed in controlling the woman.

\section{$3 \quad$ Jesus and His Mother (John 2:1-12)}

In the Gospel of John, Jesus, his mother and the disciples attend a wedding feast in Cana. When the hosts run out of wine, Jesus's mother ${ }^{10}$ tells her son about this. Jesus understands it as a request to do something about the

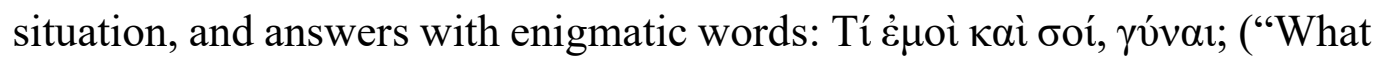
have you to do with me, woman?"; John 2:4, my translation). Jesus addresses his mother as rúval, "woman." Elsewhere in ancient Greek literature, this is a common way of addressing an unknown woman in a respectful manner (Smit 2006, 4). It is also how Jesus addresses all other

\footnotetext{
8 The opposite is true of Matt, where the woman's faith is the reason why Jesus cures her daughter.

9 The portrayal of Jesus's route is geographically odd and seems designed to show that Jesus deliberately avoided Jewish areas: "Then he returned from the region of Tyre, and went by way of Sidon towards the Sea of Galilee, in the region of the Decapolis" (Mark $7: 31$ ). Jesus thus goes North in order to get to the South-East.

${ }^{10}$ John never mentions the name of Jesus's mother. Although her relationship with Jesus is not severed, and she remains Jesus's mother throughout the Gospel (see also Gaventa 1995, 85), she does not have an identity of her own, and is only defined in relation to a man. I follow John's practice of not naming her to emphasise her devalued role in John's narrative.
} 
women in the Gospel. The address is not impolite, but its use by a son addressing his mother is peculiar. There are no parallels in ancient GrecoRoman literature for the use of the expression for one's mother (Brown 1966, 99; Smit 2006, 3-5). Although polite, it suggests a distance between Jesus and his mother. Jesus is treating his mother in the same way as any other woman.

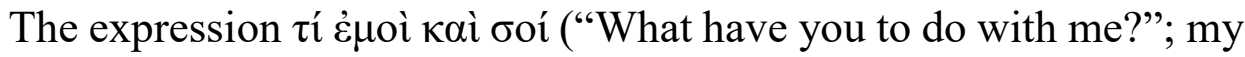
translation) increases the distance between Jesus and his mother (Smit 2006, 3 ). The expression can be found several times in the Septuagint (Judg 11:12; $1 \mathrm{Kgs} 17: 18 ; 2 \mathrm{Kgs} 3: 13 ; 2 \mathrm{Chr} 35: 21) .{ }^{11}$ For example, Elisha says to the king of Israel: "What have I to do with you? Go to your father's prophets or to your mother's" (2 Kgs 3:13). When King Josiah went against Neco, the pharaoh sent envoys to him, saying: "What have I to do with you, king of Judah? I am not coming against you today, but against the house with which I am at war" (2 Chr 35:21). The expression can also be found in the Synoptic Gospels, where the Gerasene demoniac shouts at Jesus: "What have you to do with me, Jesus, Son of the Most High God? I adjure you by God, do not torment me" (Mark 5:7; par. Matt 8:29; Luke 8:28; cf. Mark 1:24; Luke

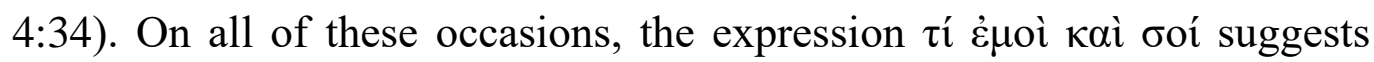
diversity of opinion or interest. Jesus's answer seems to be intended to silence his mother and order her to leave him alone.

Jesus's answer to his mother sounds rude and disrespectful. It has sometimes been argued that it is not likely that Jesus is portrayed negatively here (see, e.g., Conway 1999, 73). However, Jesus is not an ethical model in the Gospel of John. He lies to his brothers about not going to the Festival of Booths (John 7:8-10). He refuses to help his friend Lazarus in time, although he later raises him from the dead (John 11). His interactions with his friends seem occasionally questionable, not to mention the way he talks to his opponents, telling them: "You are from your father the devil" (John $8: 44)$. In this context, it is not surprising if Jesus is rude and condescending to his mother as well.

Commentators usually excuse Jesus's behaviour towards his mother by suggesting that his mother's will is less important than the will of God. They argue that Jesus treats his mother this way because in the Gospel of John, "Jesus is not his mother's child, but his Father's Son" (Smit 2006, 5). Throughout the Gospel, Jesus is defined through his allegiance to God.

\footnotetext{
${ }^{11}$ See also Epictetus (Enchiridion 2.19.16; 1.1.16). On the expression, see also Gaventa (1995, 84-85).
} 
According to this interpretation, his mother tries to push him before his time, which is what Jesus himself says: "My hour has not yet come" (John 2:4). Jesus rejects his mother's attempt to assert authority over him. This would make Jesus masculine. According to this interpretation, Jesus is not dominated by other people, which emphasises his masculine authority and autonomy (see, e.g., Smit 2006, 7-8).

The problem with this interpretation is that it overlooks the fact that, in the end, Jesus does submit to his mother. He does not refuse his mother's request, but changes his mind and provides the wedding guests with an abundance of wine. In the end, Jesus is not a hypermasculine, autonomous son who rejects his mother's authority. Moreover, his mother does not take no for an answer. Jesus tries to treat her like any other woman. His mother does not submit to her son. Completely ignoring her son's reluctance to act, she tells the servants: "Do whatever he tells you" (John 2:5). Her words to the servants express certainty that Jesus will act.

The mother's actions are not inconsistent with the rest of the narrative. She does not push Jesus before his time, but rather contributes to the doing of God's will. Jesus is wrong when he thinks that his time has not yet come (see also Conway 1999, 77-78). The mother's insistence makes Jesus perform what the Gospel writer calls "the first of his signs" (John 2:11). Providing the wine reveals Jesus's glory and as a result his disciples believe in him. His mother's actions lead Jesus to begin his public career.

When Jesus's mother does not remain silent and submissive to her son's demands, she does not follow the ideals of ancient Greco-Roman emphasised femininity. As a mother, she has a stronger claim than the Syrophoenician woman to get Jesus to do what she asks. However, Jesus tries to act in a hypermasculine way when he attempts to control and silence his mother. He tries to treat her like any other woman, which makes her position more like that of the Syrophoenician woman. Jesus's mother refuses to submit to Jesus's attempt to devalue her and insists that her son treat her with the respect due to her as a mother. While his initial behaviour towards her is rude and condescending, the fact that Jesus submits to his mother makes him an ideal son. Although Jesus's deference to his mother does not call his masculinity into question as much as deference to some other woman would, the way Jesus's mother acts still calls his masculine agency into question (and in front of witnesses, no less!). 


\section{The Samaritan Woman (John 4:5-42)}

Jesus meets the Samaritan woman by a well. They discuss several theological topics, all of which are related to the relationship between the Samaritans and the Jews. In previous studies, the woman's behaviour has often been labelled as transgressive and shameful, since she comes to draw water at noon, an unusual time for this task, and talks to Jesus instead of simply giving him water and going away silently (Neyrey 1994, 82; Esler 1994, 32-33). However, there is no basis for seeing the woman as deviant. Coming to draw water at noon was not a practice that was unheard of. In the Hebrew Bible, Rachel came to fetch water at noon (Gen 29:6-7), and Josephus (Ant. 2.257-260; cf. Exod 2:15-17) writes that the girls who were helped by Moses came to fetch water at noon. The Samaritan woman is simply conducting a typical female task. Moreover, her response to Jesus's request to give him something to drink could be seen simply as the result of her amazement at the fact that a Jewish man is asking for water from a Samaritan woman, rather than as shameful behaviour.

After Jesus's initial request for a drink, the discussion moves to the topic of living water, which Jesus professes to give. After the woman asks Jesus to give her the living water, Jesus suddenly tells her to go get her husband (John 4:16). The woman tells him: "I have no husband." Jesus answers her, beginning and ending his response by stating that the woman has spoken truthfully: "You are right in saying, 'I have no husband'; for you have had five husbands, and the one you have now is not your husband. What you have said is true!" (John 4:17-18). Scholars have speculated that the woman may have been divorced or widowed several times (BeasleyMurray 1999, 61; Sanders and Mastin 1968, 144). However, the woman's actual situation in life does not seem to be the main concern of the passage. What is more important is that she refuses to give a straight answer to Jesus's question, and instead gives an evasive response. Details of her private life are none of the stranger's business. Jesus does not allow the woman to protect herself, but exposes the truth. However, the woman is not discouraged by his response, but continues the conversation. She identifies him as a prophet and introduces the topic of the proper place of worship.

In previous studies, scholars have often noted how the woman changes the subject from her sexual history to the question about where worship should take place. Some even argue that the woman is not actually interested in the theological issue she raises. These commentators claim that she is just desperately trying to save herself after Jesus has exposed her 
morally questionable past (Bernard 1929, 145; Morris 1995, 236). ${ }^{12}$ This interpretation perpetuates the stereotype of women as incapable of serious theological thought. Is it not possible that the woman was truly interested in religious matters? The Samaritan woman's interest in theological topics, especially the relationship between Jews and Samaritans, is evident throughout the discussion, starting from the first question she asks Jesus: "How is it that you, a Jew, ask a drink of me, a woman of Samaria?" (John $4: 9)$.

The woman continues the dialogue on the same topic that has interested her throughout the conversation, namely the relationship between Jews and Samaritans. Scholars have failed to note that it is actually Jesus who changes the topic from a theological issue to the woman's sexual history. There is no explicit reason why he needs to ask for her husband instead of trying to explain his meaning in a different way, as he does with Nicodemus in the previous chapter, John 3. Why does Jesus change the subject, and why does he divert the conversation to this particular subject, namely the woman's marital status and sexual history?

Commentators have usually excused Jesus's behaviour by arguing that this is how he shows the woman that he is a prophet (see, e.g., Seim 1986, 68; O'Day 2002, 50). However, this does not change the fact that Jesus is quite rude and uses the Samaritan woman's gender and sexual behaviour to make a point. Although Jesus does not explicitly condemn the woman's sexual history, bringing it up is a form of "slut shaming," which is an attempt to control and denigrate women who are perceived to transgress traditional expectations related to sexual behaviour. When scholars argue that the woman must have been sexually deviant, they partake in victimblaming: she must have "deserved it." Is there no other way for Jesus to show that he is a prophet than by talking about the woman's marital history and sex life? Moreover, is it Jesus's intention that the woman should identify him as a prophet, or does this interpretation simply follow from the fact that the woman does so? The fact that the woman calls him a prophet does not mean that Jesus intended her to do so, just as the Syrophoenician woman talking about dogs under the table does not mean that Jesus is talking about household pets. It is the Syrophoenician woman who introduces the notion of the table and changes the meaning of the parable. Similarly, the Samaritan

\footnotetext{
${ }^{12}$ See also Frances Taylor Gench $(2004,117)$, who points out that many commentators see the woman's response not as a serious theological query, but as "a smokescreen," or "a 'desperate' attempt to change the topic."
} 
woman refuses Jesus's attempt to derail the conversation and silence her by changing the subject to her sexual history, insisting that they continue to discuss theological issues. She also resembles Jesus's mother, who is not discouraged by his attempt to silence her either. All three women refuse to be silenced. Their behaviour does not follow the ancient Greco-Roman ideals of emphasised femininity. At the same time, their behaviour challenges Jesus's masculinity when Jesus is unable to control these women.

In the end, the conversation leads to the first "I am" statement in the Fourth Gospel. Jesus answers the woman's speculation about the coming Messiah with "I am he, the one who is speaking to you" (John 4:26). Jesus finally manages to speak clearly. The woman goes to tell the villagers about her encounter with Jesus. As a result of her actions, the Samaritan people ask Jesus to stay with them, hear his words, and believe (John 4:40-41). The woman's persistence eventually leads to the first "I am" statement, the revelation of Jesus's identity, and the conversion of the Samaritan villagers.

\section{The Three Women, Jesus, and Constructions of Gender}

The Syrophoenician woman, Jesus's mother and the Samaritan woman act in similar ways. They refuse to be silenced or mistreated by Jesus and talk back. Their answer leads Jesus to change his mission. As a result of the meeting with the Syrophoenician woman, Jesus begins his mission among gentiles; the actions of Jesus's mother lead Jesus to begin his public career; and the Samaritan woman procures the first "I am" statement, which leads to the conversion of the villagers. When these women challenge Jesus, they do not adhere to the ancient Greco-Roman ideals of emphasised femininity, according to which women were supposed to be silent and submissive. These women refuse to act in ways deemed suitable for women. They do not submit and they do not shut up. Unlike several other stories, where other people learn lessons from Jesus, Jesus is the one who has to learn a lesson in these three narratives. Not only are these three women "out of place," their behaviour also affects Jesus's masculinity. Jesus is not able to control these women or their speech, which calls his masculinity into question.

The Gospel narratives are phallogocentric in general, so that these three encounters with women are exceptions rather than the rule. Moreover, the voice of Jesus prevails in the end, while the women fall into the background. Although Mark describes the Syrophoenician woman's experience of going back home and finding her daughter healed, she does not become part of Jesus's mission from that point on. Jesus's mother is next seen at the end of John's Gospel, where she does not speak and Jesus 
provides for her future. The villagers tell the Samaritan woman that after they have seen and heard Jesus, "[i]t is no longer because of what you said that we believe, for we have heard for ourselves, and we know that this is truly the Saviour of the world" (John 4:42). Once she has announced Jesus, she never speaks again (see also Dube 1996, 52-53). Although these three women shape Jesus's ministry in important ways, they need acceptance from a man to be successful. Their behaviour challenges Jesus's masculinity, but in the end, the status quo of gender relations remains unchanged.

Jesus attempts to shame these women back into their place. From the modern perspective, Jesus acts inappropriately. ${ }^{13}$ This has rarely if ever been noted in previous studies, which have usually tried to excuse Jesus's behaviour and make it acceptable. Jesus (of the Gospels at least) is not a nice guy. He is not a feminist. On the contrary, he displays features of what today would be called toxic masculinity: a set of behaviours that are harmful to both men and women. These behaviours include dominance and the devaluation of women.

Jesus's mother has a stronger claim for her request to him than the two other women, who are strangers. In addition to their gender, the Syrophoenician and Samaritan women are marginalised because of their ethnicity; in other words, gender and ethnicity intersect. It is possible that, in addition to their gender, the women's ethnic background is the reason for Jesus's behaviour and his attempts to silence them. ${ }^{14}$ Elsewhere in the Gospels, Jesus is willing to help Jewish women in need. It seems that the women in the margins have a greater need to transgress the boundaries of acceptable gender behaviour in order to overcome the obstacles introduced by Jesus. It is possible that the Gospel writers wished to portray Jewish women as more ideally feminine, as characters who do not transgress the boundaries of appropriate behaviour, but remain silent while men talk about them. Although the Samaritan and Syrophoenician women come from the margins, they are essential in the development of Jesus's mission. Perhaps

\footnotetext{
${ }^{13}$ Jesus's rudeness is not limited to the four Gospels in the NT. In the Infancy Gospel of Thomas, the child Jesus acts inappropriately towards several people, including his parents.

${ }^{14}$ Interestingly, in New Comedy (that is, Greek comedy lasting from about 320 BCE to the mid-third century BCE), strong-willed women were also foreigners. Vincent J. Rosivach $(1998,6-7)$ notes that their marginality counterbalances their strong personality. These women are either domesticated in marriage or relegated to a proper, marginal place. Something similar happens in the Gospels: the unruly women are domesticated back under the control of a man.
} 
it is necessary that they come from the margins. These women must be "out of place" so that they can teach Jesus and influence his mission.

\section{Conclusions}

The Syrophoenician woman, the Samaritan woman and Jesus's mother behave in ways that would have been considered "out of place" from the point of view of the ancient Greco-Roman ideals. They are not silent and submissive, and thus do not observe the ancient Greco-Roman ideals of emphasised femininity. Jesus attempts to put these unruly women back in their proper place. Undaunted by Jesus's behaviour, the three women refuse to be silenced. Their behaviour also poses a challenge to Jesus's masculinity. According to the ancient Greco-Roman hegemonic masculinity, men should be able to control women and demonstrate authority. When Jesus is unable to do this, his masculinity is called into question. At the same time, the women themselves display masculine ideals of persuasive speech and courage.

\section{Bibliography}

Alonso, Pablo. 2011. The Woman Who Changed Jesus: Crossing Boundaries in Mk 7,2430. Leuven: Peeters [BTS 11].

Asikainen, Susanna. 2018. Jesus and Other Men: Ideal Masculinities in the Synoptic Gospels. Leiden: Brill [BibInt 159].

Beasley-Murray, George R. 1999. John. Nashville: Thomas Nelson [WBC 36].

Bernard, J. H. 1929. A Critical and Exegetical Commentary on the Gospel according to St. John. New York: Charles Scribner's Sons [ICC 29].

Brown, Raymond E. 1966. The Gospel according to John (I-XII): Introduction, Translation and Notes. New York: Doubleday [AB 29].

Burkill, T. A. 1967. The Historical Development of the Story of the Syrophoenician Woman (Mark VII:24-31). NovT 9:161-177.

Connell, R. W. 1987. Gender and Power: Society, the Person and Sexual Politics. Cambridge: Polity. 2005. Masculinities. 2d ed. Cambridge: Polity.

Conway, Colleen M. 1999. Men and Women in the Fourth Gospel: Gender and Johannine Characterization. Atlanta: SBL [SBLDS 167].

Dube, Musa W. 1996. Reading for Decolonization (John 4:1-42). Semeia 75:37-59.

Esler, Philip Francis. 1994. The First Christians in Their Social Worlds: Social-Scientific Approaches to New Testament Interpretation. London: Routledge.

Filson, Floyd Vivian. 1971. A Commentary on the Gospel according to St. Matthew. London: Adam \& Charles Black [BNTC].

France, R. T. 2007. The Gospel of Matthew. Grand Rapids: Eerdmans [NICNT]. 
Gaventa, Beverly Roberts. 1995. Mary: Glimpses of the Mother of Jesus. Columbia, SC: University of South Carolina Press.

Gench, Frances Taylor. 2004. Back to the Well: Women's Encounters with Jesus in the Gospels. Louisville: Westminster John Knox.

Gundry, Robert Horton. 1994. Matthew: A Commentary on His Handbook for a Mixed Church under Persecution. Grand Rapids: Eerdmans.

Kartzow, Marianne Bjelland. 2009. Gossip and Gender: Othering of Speech in the Pastoral Epistles. Berlin: de Gruyter.

Keener, Craig S. 1999. A Commentary on the Gospel of Matthew. Grand Rapids: Eerdmans.

Lane, William L. 1975. The Gospel according to Mark: The English Text with Introduction, Exposition and Notes. Grand Rapids: Eerdmans [NICNT].

Luz, Ulrich. 2001. Matthew 8-20: A Commentary. Translated by James E. Crouch. Edited by Helmut Koester. Minneapolis: Fortress [Hermeneia].

Metzger, Bruce M. 1994. A Textual Commentary on the Greek New Testament. 2d ed. Stuttgart: United Bible Societies.

Morris, Leon. 1995. The Gospel according to John. Grand Rapids: Eerdmans [NICNT].

Moxnes, Halvor. 2003. Putting Jesus in His Place: A Radical Vision of Household and Kingdom. Louisville: Westminster John Knox.

Neyrey, Jerome H. 1994. What's Wrong with This Picture? John 4, Cultural Stereotypes of Women, and Public and Private Space. BTB 24:77-91.

Nolland, John. 2005. The Gospel of Matthew: A Commentary on the Greek Text. Grand Rapids: Eerdmans [NIGTC].

O'Day, Gail. 2002. The Word Disclosed: Preaching the Gospel of John. Rev. ed. Atlanta: Chalice.

Økland, Jorunn. 2004. Women in Their Place: Paul and the Corinthian Discourse of Gender and Sanctuary Space. London: T\&T Clark.

Rhoads, David. 1994. Jesus and the Syrophoenician Woman in Mark: A Narrative-Critical Study. JAAR 62:343-375.

Rosivach, Vincent J. 1998. When a Young Man Falls in Love: The Sexual Exploitation of Women in New Comedy. London: Routledge.

Sanders, J. N., and B. A. Mastin. 1968. A Commentary on the Gospel according to St John. London: Black [BNTC].

Seim, Turid Karlsen. 1986. Roles of Women in the Gospel of John. Pages 56-73 in Aspects on the Johannine Literature: Papers Presented at a Conference on Scandinavian New Testament Exegetes at Uppsala, June 16-19, 1986. Edited by Lars Hartman and Birger Olsson. Stockholm: Almqvist \& Wicksell.

Smit, Peter-Ben. 2006. Jesus and the Ladies: Constructing and Deconstructing Johannine Macho-Christology. The Bible and Critical Theory 3(2):1-15.

Taylor, Vincent. 1952. Gospel according to St. Mark: The Greek Text with Introduction, Notes, and Indexes. London: Macmillan.

Treggiari, Susan. 1991. Roman Marriage: Iusti Coniuges from the Time of Cicero to the Time of Ulpian. Oxford: Clarendon.

Von Lips, Hermann. 1988. Schweine füttert man, Hunde nicht: Ein Versuch, das Rätsel von Matthäus 7:6 zu lösen. ZNW 79:165-186. 
Williams, Craig A. 1999. Roman Homosexuality: Ideologies of Masculinity in Classical Antiquity. Oxford: Oxford University Press.

susanna.asikainen@helsinki.fi

Faculty of theology, PL 4 (Vuorikatu 3), 00014, University of Helsinki, Finland 